\title{
Jurist-Diction
}

Volume 3 No. 5, September 2020

\section{Kewenangan Komisi Aparatur Sipil Negara Dalam Pengawasan Sistem Merit}

\author{
Diasa Inas Wishesa \\ diasa.inas.wishesa-2016@fh.unair.ac.id \\ Universitas Airlangga
}

How to cite:

Diasa Inas Wishesa,

'Kewenangan Komisi Aparatur Sipil Negara Dalam Pengawasan Sistem Merit' (2020) Vol. 3 No. 5 JuristDiction.

Histori artikel:

Submit 30 Juli 2020;

Diterima 14 Agustus 2020;

Diterbitkan 1 September 2020.

DOI:

10.20473/jd.v3i5.21969

\begin{abstract}
Abstrak
Aparatur Sipil Negara (ASN) yang terdiri dari Pegawai Negeri Sipil (PNS) dan Pegawai Pemerintah dengan Perjanjian Kerja (PPPK) sebagai profesi yang memiliki tujuan pengabdian pada negara melalui peran penyelenggaraan pelayanan publik dengan mengedepankankan profesionalitas dan integritas dalam melaksanakan tugas dan fungsinya serta bersifat netral dan bebas dari intervensi politik. Undang-Undang Kepegawaian dengan perubahan terbaru diatur dalam Undang-Undang Nomor 5 Tahun 2014 tentang Aparatur Sipil Negara dengan diamanatkan pula Sistem Merit sebagai sistem yang mendasari pengisian jabatan tinggi secara terbuka dan pelaksanaan sistem tersebut pada seluruh instansi. Dengan adanya Sistem Merit, dibentuklah Komisi Aparatur Sipil Negara (KASN) yang memiliki wewenang untuk mengawasi penerapan Sistem Merit dalam kebijakan dan manajemen ASN, juga terhadap pelaksanaan norma dasar, kode etik, dann kode perilaku ASN berdasarkan perolehan kewenangan secara delegasi dari Presiden melaui undang-undang dengan tanggung jawab berada pada penerima delegasi.

Kata Kunci: Pegawai Negeri Sipil; Komisi Aparatur Sipil Negara; Sistem Merit; Pengawasan; Tanggung Jawab.
\end{abstract}

\section{Pendahuluan}

Undang-Undang Dasar Negara Republik Indonesia 1945 sebagai fondasi kehidupan berbangsa dan bernegara yang di dalamnya menjamin hak warga negara yang salah satunya hak untuk memperoleh pekerjaan dan pengihidupan yang layak sebagaimana disematkan dalam Pasal 28D Undang-Undang Dasar 1945. Perolehan pekerjaan merupakan hal yang berkaitan dengan pemenuhan pekerjaan yang salah satunya melalui profesi yang memiliki tujuan pengabdian pada negara dengan kriteria memiliki integritas tinggi, profesional, bersifat netral dan bebas dari intervensi politik dalam melaksanakan tugasya. Dalam hal ini Aparatur Sipil Negara (ASN) merupakan profesi yang wajib memenuhi kriteria tersebut dengan tujuan menjalankan tugas pemerintahan serta melayani masyrakat 
berdasarkan peraturan perundang-undangan. ASN diatur dalam dalam UndangUndang Nomor 5 Tahun 2014 tentang Aparatur Sipil Negara terdiri dari Pegawai Negeri Sipil (PNS) berdasarkan Pasal 1 angka 3 UU ASN adalah warga negara Indonesia yang memenuhi syarat yang telah ditentukan dan diangkat sebagai pegawai ASN secara tetap oleh pejabat pembina kepegawaian untuk menduduki jabatan pemerintahan dan Pegawai Pemerintah dengan Perjanjian Kerja (PPPK) berdasarkan Pasal 1 angka 4 UU Nomor 5 Tahun 2014 adalah warga negara Indonesia yang telah memenuhi syarat tertentu yang telah di tetapkan, yang diangkat berdasarkan perjanjian kerja untuk jangka waktu tertentu dalam rangka melaksanakan tugas pemerintahan, kedudukan ASN dalam penyelenggaraan pemerintahan sangat penting untuk menentukan tujuan nasional sehingga terwujud cita-cita pembangunan nasional. ${ }^{1}$

Dalam melanjalankan profesi dan manajemen ASN didasarkan Sistem Merit yang diatur dalam Pasal 1 angka 22 UU Nomor 5 Tahun 2014 merupakan kebijakan manajemen ASN yang berdasarkan kualifikasi, kompetensi, dan kinerja secara adil dan wajar tanpa membedakan latar belakang politik, ras, warna kulit, agama, asal usul, jenis kelamin, status pernikahan, umur, atau kondisi kecacatan. Sistem Merit diimplementasikan pada pengangkatan Jabatan Pemimpin Tinggi dan pelaksanaan dalam instansi pemerintahan.

Dengan diamanatkannya Sistem Merit dalam UU Nomor 5 Tahun 2014 dan diimplementasikan dalam penyelenggaraan pemerintahan kemudian dibentuklah sebuah lembaga yang mandiri dan independen yang memiliki tugas dan fungsi mengawasi Sistem Merit dalam melaksanakan monitoring, evaluasi pelaksanaan kebijakan serta penerapkan kode perilaku dan kode etik perilaku bagi ASN yaitu Komisi Aparatur Sipil Negara (KASN). Pengawasan yang dilakukan oleh KASN sebagai wujud tanggung jawab atas kewenangan yang didapat berdasarkan peraturan perundang-undangan dan Asas-Asas Umum Pemerintahan yang Baik (AUPB) dengan tujuan memastikan instansi pemerintah melaksanakan Sistem Merit secara

${ }^{1}$ Effendi Sofyan, Manajemen Pelayanan Umum (Usaha Nasional 1997).[24]. 
konsisten berdsarkan UU ASN serta melaksanakan pengawasan Sistem Merit dalam Pengisian Jabatan Tinggi dan pelaksanaan instansi pemerintahan. ${ }^{2}$

Terkait kewenangan KASN dalam mengawasi dan mengevaluasi penerapan asas, nilai dasar, serta kode etik dan kode perilaku pegawai ASN, telah ditemukan 103 kasus pada tahun 2018 yang sudah diselesaikan berjumlah 57 kasus, sedang berjalan 46 kasus. $^{3}$ Sejak tahun 2014 banyak terjadi pelanggaran sistem merit baik di Kementerian/Lembaga maupun pada instansi pemerintah daerah yakni Provinsi dan Kabupaten/Kota. Tahun 2018 terdapat 211 kasus pelanggaran sistem merit berupa pengangkatan, pemindahan dan pemberhentian ASN dari dan dalam Jabatan Pimpinan Tinggi (JPT), Jabatan Administaror (Pengawas dan Pelaksana), dan jabatan fungsional tertentu yang tidak sesuai mekanisme serta prosedur yang berlaku, dimana terdapat 128 kasus telah selesai dan 83 kasus dalam proses penelaahan dan permintaan data tambahan. ${ }^{4}$ Pengaduan bagi ASN yang melanggar ditujukan pada KASN dengan penyelesaian secara mediasi dan perlindungan yang dilakukan oleh Kelompok Kerja (Pokja) dengan tujuan memfasilitasi penyelesaian sengketa melalui mediasi dan arbitrase secara adil, transparan dan menyeluruh. Mediasi dan perlindungan yang dilakukan untuk menghindarkan ASN dari intervensi politik terhadap birokrasi. ${ }^{5}$

\section{Rumusan Masalah}

Berdasarkan uraian tersebut di atas, maka diketahui permasalahan yang akan dikaji dalam penelitian ini adalah :

1. Eksistensi Komisi Aparatur Sipil Negara dalam pengawasan Sistem Merit;

2. Tanggung jawab Komisi Aparatur Sipil Negara terhadap pelanggaran pengawasan Sistem Merit.

\footnotetext{
${ }^{2}$ Komisi Aparatur Sipil Negara, 'Laporan Komisi Aparatur Sipil Negara 2018', (KASN, 2019), <www.KASN.go.id $>$ accessed 14 Agustus 2019

${ }^{3}$ ibid.

${ }^{4}$ ibid.

5 ibid. [35].
} 


\section{Eksistensi Komisi Aparatur Sipil Negara dalam pengawasan Sistem Merit}

Asas legalitas sebagai prinsip utama dalam setiap negara hukum, yaitu sebagai dasar untuk penyelenggaraan kenegaraan dan pemerintahan. ${ }^{6}$ Selain itu, asas legalitas juga sebagai bentuk perlindungan hukum kepada masyarakat dari tindakan kesewenangan oleh pemerintah dan sebagai bentuk legitimasi atas tindakan pemerintah untuk mengetahui kewenangan dasar yang dimiliki serta senagai bentuk dari kepastian atas tindakan yang dilakukan oleh pemerintah. ${ }^{7}$

Wewenang merupakan hak dan kekuasaan untuk bertindakm kekuasaan membuat keputusan, memerintah, dan melimpahkan kewajiban yang dimiliki. ${ }^{8}$ HD Stout mengatakan : "Wewenang merupakan pengertian yang berasal dari hukum organisasi pemerintahan, yang dapat dijelaskan sebagai keseluruhan aturan yang berkenaan dengan perolehan dan penggunaan wewenang pemerintahan oleh subyek hukum publik dalam hubungan hukum publik". Berdasarkan definisi terkait kewenangan dia atas, maka kewenangan merupakan sebuah hak yang dimiliki badan atau pejabat pemerintah untuk melaksanakan fungsi yang diberikan padanya dan bersumber dari peraturan perundang-undangan sebagai sebuah kepastian dalam bertindak dengan tujuan untuk menciptakan hubungan hukum antara penyelenggara kekuasan dan masyarakat sebagai bentuk perlindungan hukum bagi masyarakat sendiri.

Berdasarkan Undang-Undang Nomor 30 Tahun 2014 tentang Administrasi Pemerintahan, bahwa kewenangan diperoleh melalui atribusi, delegasi, dan mandat. Atribusi sebagai sebagai wewenang baru atau wewenang yang sebelumnya tidak ada pada Badan dan/atau Pejabat Pemerintahan yang diberikan oleh UndangUndang Dasar Negara Republik Indonesia Tahun 1945 atau Undang-Undang dengan beban tanggung jawab melekat pada Badan dan/atau Pejabat Pemerintahan

\footnotetext{
6 Juniarso Ridwan dan Achmad Sodik Sudrajat, Hukum Administrasi dan Pelayanan Publik (Nuansa Cendekia 2019).[136]

7 Lukman Hakim, 'Kewenangan Organ Negara Dalam Penyelenggaraan Pemerintahan' (2011) Jurnal Konstitusi.[2].

8 Kamal Hidjaz, Efektivitas Penyelenggaraan Kewenangan Dalam Sistem Pemerintahan Daerah di Indonesia (Pustaka Refleksi 2010).[35].
} 
yang melaksanakan wewenang tersebut serta wewenang ini tidak dapat dilimpahkan atau di delegasikan kepada pihak la. Selanjutnya, kewenangan secara delegasi merupakan pelimpahan wewenang dari Badan dan/atau Pejabat Pemerintahan yang lebih tinggi pada yang lebih rendah berdasarkan penetapan peraturan perundangundangan dengan tanggung jawab dan tanggung gugat beralih sepenuhnya kepada penerima delegasi. Kemudian, perolehan kewenangan secara mandat merupakan bentuk pelimpahan wewenang dari Badan dan/atau Pejabat Pemerintahan yang lebih tinggi pada yang lebih rendah dengan tanggung gugat dan tanggung gugat berada pada pemberi mandat.

Menurut Philipus M. Hadjon, bahwa tindakan yang dilakukan oleh pemerintah disyaratkan berlandaskan pada kewenangan yang sah. Kewenangan tersebut dapat diperoleh melalui atribusi, delegasi dan mandat. Perolehan Kewenangan secara atribusi digariskan berdasarkan pembagian kekuasaan negara oleh dasar negara yakni Undang-Undang Dasar, sedangkan perolehan Kewenangan melalui delegasi dan mandat berdasarkan pelimpahan. Philipus M. Hadjon pada dasarnya membuat perbedaan mendasar terkait perolehan kewenangan secara delegasi dan perolehan kewenangan secara mandat. Pada perolehan Kewenangan secara delegasi prosedur pelimpahannya berasal dari organ pemerintahan ke organ pemerintahan yang lain melaui peraturan perundang-undangan serta pada tanggung jawab dan tanggung gugat yang dimiliki beralih pada penerima delegasi atau delegataris, sehingga pemberi delegasi tidak dapat melaksanakan kewenangan tersebut lagi. Sedangkan perolehan Kewenangan secara mandat, yaitu prosedur pelimpahannya terjadi dalam rangka hubungan antara atasan dan bawahan secara rutin, serta terkait tanggung jawab dan tanggung gugat jabatan tetap pada pemberi mandat. ${ }^{9}$

\section{Kewenangan Komisi Aparatur Sipil Negara}

Komisi Aparatur Sipil Negara (KASN) merupakan lembaga nonstruktural yang mandiri dan bebas dari intervensi politik. Kewenangan KASN diperoleh

\footnotetext{
9 Ridwan HR, Hukum Administrasi negara (Raja Grafindo Persada 2013). [108-109].
} 
melalui Presiden berdasarkan pasal 25 UU Nomor 5 Tahun 2014 bahwa secara definitif Presiden mendelegasikan sebagaian sebagian kekuasaannya selaku pemegang kekuasaan pemerintahan sebagai pemegang kekuasaan tertinggi dalam kebijakan, pembinaan profesi, dan Manajemen ASN kepada KASN berkaitan dengan kewenangan monitoring dan evaluasi pelaksanaan kebijakan dan Manajemen ASN untuk menjamin perwujudan Sistem Merit serta pengawasan terhadap penerapan asas serta kode etik dan kode perilaku ASN. Perolehan kewenangan delegasi KASN dari Presiden merupakan bentuk pemberian wewenang dari suatu badan atau pejabat pemerintahan kepada badan atau pejabat pemerintahan lain sehingga Presiden tidak memiliki lagi kewenangan yang telah dilimpahkan kepada KASN, hal ini bersesuaian dengan syarat pelimpahan wewenang pemerintah melalui delegasi bahwa pemberi delegasi tidak dapat lagi menggunakan sendiri wewenang yang telah dilimpahkan.

Berdasarkan hal tersebut, kewenangan KASN diatur dalam Pasal 32 UU Nomor 5 Tahun 2014, yakni :

(1) KASN berwenang:

a. mengawasi setiap tahapan proses pengisian Jabatan Pimpinan Tinggi mulai dari pembentukan panitia seleksi instansi, pengumuman lowongan, pelaksanaan seleksi, pengusulan nama calon, penetapan, dan pelantikan Pejabat Pimpinan Tinggi;

b. mengawasi dan mengevaluasi penerapan asas, nilai dasar serta kode etik dan kode perilaku Pegawai ASN;

c. meminta informasi dari pegawai ASN dan masyarakat mengenai laporan pelanggaran norma dasar serta kode etik dan kode perilaku Pegawai ASN;

d. memeriksa dokumen terkait pelanggaran norma dasar serta kode etik dan kode perilaku Pegawai ASN; dan

e. meminta klarifikasi dan/atau dokumen yang diperlukan dari Instansi Pemerintah untuk pemeriksaan laporan atas pelanggaran norma dasar serta kode etik dan kode perilaku Pegawai ASN.

(2) Dalam melakukan pengawasan sebagaimana dimaksud pada ayat (1) huruf $b$, KASN berwenang untuk memutuskan adanya pelanggaran kode etik dan kode perilaku Pegawai ASN.

(3) Hasil pengawasan sebagaimana dimaksud pada ayat (1) huruf a dan huruf b disampaikan kepada Pejabat Pembina Kepegawaian dan Pejabat yang Berwenang untuk wajib ditindaklanjuti. 


\section{Tanggung Jawab Komisi Aparatur Sipil Negara dalam Sistem Merit}

Sistem Merit diatur dalam UU Nomor 5 Tahun 2014 yang merupakan sebuah kebijakan dan Manajemen ASN yang berdasarkan pada kualifikasi, kompetensi, dan kinerja secara adil dan wajar dengan tanpa membedakan latar belakang politik, ras, warna kulit, agama, asal usul, jenis kelamin, status pernikahan, umur, atau kondisi kecacatan. Sistem Merit didefinisikan sebagai pengelolaan sumber daya manusia yang didasarkan pada prestasi yaitu perilaku kerja pegawai dalam hal baik atau buruk yang berpengaruh secara langsung pada jabatan yang dimiliki. ${ }^{10}$ Dengan lahirnya UU Nomor 5 Tahun 2014 slah satu bentuk produk hukum yang mengawali reformasi birokrasi dengan menerapkan Sistem Merit dengan tujuan mewujudkan ASN yang memiliki integritas, profesional, netral, bebas dari intervensi politik, bebas dari praktik korupsi, kolusi dan nepotisme serta menyelenggarakan pelayanan publik bagi masyarakat dan mampu menjalankan peran sebagai unsur pemersatu bangsa. ${ }^{11}$ Pelaksanaan Sistem Merit secara umum diatur dalam Undang-Undang ASN terkait pengisian Jabatan Pimpinan Tinggi (JPT) melalui seleksi terbuka dan penerapan prinsip-prinsip merit pada instansi pemerintah dalam manajemen ASN. Selanjutnya diatur secara khusus dalam Peraturan Menteri Pendayagunaan Aparatur Negara dan Reformasi Birokrasi Nomor 40 Tahun 2018 Tentang Pedoman Sistem Merit Dalam Manajemen Aparatur Sipil Negara.

Upaya perlindungan hukum merupakan upaya yang bersifat represif sebagai Tanggung Jawab dalam penyelggaraan pemerintahan sebagai upaya hukum yang bersifat represif. Tanggung jawab diperukan untuk mengetahui siapa yang bertanggung jawab atas tugas pemerintahan dan pelayan apa yang diberikan kepada masyarakat, maka perlu dikemukakan terlebih dahulu terkait bagaimana tanggung jawab dalam jabatan pemerintahan yang melekat pula fungsi dan kewenangan

\footnotetext{
10 Jiwo Wungu, 'Merit System' (Raja Grafindo 2003).[24].

11 Wawan dan Rohidin Sudarno, 'Pelaksanaan Sistem Merit Dalam UU ASN, Wewenang KASN dan Analisis Peraturan Perundang-Undangan yang Berpengaruh Terhadap Kewenangan KASN' (2018) Jurnal Mozaik.[29].
} 
pemerintahan. ${ }^{12}$ Tugas dan wewenang pemerintahan melekat pada jabatan dijalankan oleh pribadi yang bertindak sebagai pemangku jabatan atau pejabat pemerintahan, hal ini dikarenakan wewenang yang melekat pada jabatan selalu disertai dengan tanggung jawab berdasarkan prinsip "deen bevoegdheid zonder " yaitu tidak ada kewenangan tanpa pertanggung jawaban. ${ }^{13}$ Karena wewenang melekat pada jabatan sedangkan implementasi nya dilaksanakan oleh pribadi selaku fungsionaris jabatan, maka yang menerima beban tanggung jawab hukum saat terjadi penyelewengan wewenang harus dilihat secara kasuistik karena dalam tanggung jawab terdapat berupa tanggung jawab jabatan dan tanggung jawab pribadi serta tanggung gugat. ${ }^{14}$

Dalam kamus hukum terdapat 2 (dua) istilah yang merujuk pada pertanggung jawaban yakni responsbility dan liability, istilah responsbility merujuk pada tanggung jawab dan istilah liability merujuk pada tanggung gugat yang merupakan bentuk spesifik dari tanggung jawab. ${ }^{15}$

Responsiblity yaitu "the state of being answerable for an obligation, and inckudes judgment, skill, ability and capsity" yang merupakan hal kewajiban atau hal yang dapat dipertanggung jawabkan yang di dalamnya berupa putusan, keterampilan, kemampuan dan kecakapan. Berdasarkan definisi responsibility tersebut kemudian muncul istilah baru yaitu responsible goverment yang merujuk pada tanggung jawab yang diemban oleh penguasa dalam hal tindakan di bidang publik atau negara pada kementerian atau lembaga eksekutif, jika ditemukan celaan memiliki kewajiban untuk mengundurkan diri. Dari adanya penjelasan di atas, dapat ditarik bahwa responsibility merupakan bentuk pertanggung jawaban kepada parlemen secara politik yang meliputi collective and individual responsibility. ${ }^{16}$

\footnotetext{
${ }^{12}$ Merry Tjoanda, 'Analisis Tentang Tanggung Gugat dalam Kontrak Pengadaan Barang dan Jasa', (2019) < https://fhukum.unpatti.ac.id/korupsi/253-analisis-tentang-tanggung-gugat-dalamkontrak-pengadaan-barang-dan-jasa-pemerintah> accessed 15 November 2019.

13 M. Ikbar Andi Endang, 'Diskresi dan Tanggung Jawab Pejabat Pemerintahan Menurut Undang-Undang Administrasi Pemerintahan’, (2018) Jurnal Hukum Peratun.[232].

${ }_{14}$ Julista Mustamu, 'Diskresi dan Tanggungjawab Administrasi Pemerintahan', (2011) Jurnal Sasi.[6].

${ }_{15}$ Merry Tjoanda, Loc.Cit.

16 Tatiek Sri Djatmiati et al., Buku Ajar Hukum Perizinan (Fakultas Hukum Universitas Airlangga 2012).[64].
} 
Sedangkan, Liability mendekati makna komprehensif meliputi hanpir keselurhan resiko dan tanggung jawab yang sudah pasti, pun di definisikan pada seluruh karekter hak dan kewajiban. Liability juga merupakan keadaan dimana secara hukum diwajibkan untuk bertanggung jawab kepada orang lain atau masyarakat melaui upaya hukum pidana atau perdata. ${ }^{17}$ Menurut Tatiek Sri Djatmiati mengenai tanggung gugat hukum publik menyebutkan sebagai tanggung jawab jabatan dan tanggung jawab pribadi. ${ }^{18}$

Tanggung jawab Jabatan berdasarkan pendapat Logemann dijelaskan bahwa hak dan kewajiban dalam jabatan berjalan terus tidak peduli dengan pergantian jabatan karena kewenangan melekat jabatan karena tanggung jawab dalam bidang publik terkait dengan kewenangan, sehingga beban tanggung jawab pada dasarnya juga melekat pada jabatan tersebut. ${ }^{19}$

Menurut Tatiek Sri Djatmiati “tanggung jawab jabatan berkaitan dengan legalitas (keabsahan) tindak pemerintahan; dalam hukum administrasi tentang legalitas tindak pemerintahan berkaitan dengan pendekatan kekuasaan pemerintahan." Pendekatan kekuasaan berkaitan dengan wewenang yang diberikan menurut undang-undang berdasarkan prinsip legalitas atau prinsip rechmatigheid. ${ }^{20}$ Pada tanggung jawab jabatan legalitas (keabsahan) pemerintah meliputi wewenang, prosedur, dan substansi pada setiap tindakan melanggar peraturan perundangundangan dan Asas-asas Umum Pemerintahan yang Baik (AUPB) dengan sanksi berupa sanksi administrasi dan perdata. ${ }^{21}$

Tanggung jawab Pribadi merupakan bentuk pertanggung jawaban atas suatu kewenangan pada jabatan yang diemban. Menurut Tatiek Sri Djatmiati bahwa "tanggung jawab pribadi berkaitan dengan pendekatan fungsionaris atau

\footnotetext{
17 ibid. [66].

18 Deny Pala'langan, 'Tanggung Gugat Perusahaan Penerbangan terhadap Kehilangan Bagasi Penumpang'. (2017) Lex st Societas. [94].

${ }^{19}$ Merry Tjoanda, Loc.Cit.

20 Tatiek Sri Djatmiati, Tanggung Jawab Pribadi dan Tanggung Jawab Jabatan, (Alumni Universitas Trisakti 2010).[94-95].

21 Tatiek Sri Djatmiati, Hukum Administrasi dan Tindak Pidana Korupsi, (Gadjah Mada University Press 2011).[20-21].
} 
pendekatan perilaku, dari sudut pandang hukum administrasi bahwa tanggung jawab pribadi berkenaan dengan administrasi dalam penggunaan wewenang dalam pelayanan publik". penggunaan wewenang yang dimaksud meliputi tindakan pemerintah menurut peraturan perundang-undangan yang berlaku dan tindakan dalam menetapkan suatu kebijakan atau diskresi. ${ }^{22}$ Tanggung jawab pribadi dalam jabatan berkaitan dengan maladministrasi dalam wewenang, dalam hal pejabat melaksanakan tugas dan kewenangan pada jabatan nya atau membuat kebijakan akan dibebani tanggung jawab pribadi saat melakukan tindakan maladministrasi. ${ }^{23}$

Konsep tanggung jawab jabatan pelaksanaannya di implementasi dalam Undang-Undang Nomor 5 Tahun 1986 Tentang Peradilan Tata Usaha Negara selanjutnya disingkat UU PTUN dan peraturan pelaksanaannya, dengan adanya konsep tanggung jawab jabatan kemudian muncul konsep tanggung jawab pribadi utamanya setelah muncul Undang-Undang Nomor 9 Tahun 2004 Tentang Perubahan atas UU PTUN dan diimplementasikan. Pada Pasal 116 ayat (4) UU PTUN "Dalam hal tergugat tidak bersedia melaksanakan putusan Pengadilan yang telah memperoleh kekuatan hukum tetap, terhadap pejabat yang bersangkutan dikenakan upaya paksa berupa pembayaran sejumlah uang paksa dan/atau sanksi administratif” dan ayat (5) "pejabat yang tidak melaksanakan putusan Pengadilan sebagaimana dimaksud pada ayat (4) diumumkan pada media massa cetak setempat oleh Panitera sejak tidak tepenuhinya ketentuan sebagaimana dimaksud pada ayat (3)". Bahwa dalam penjelasan Pasal 116 UU PTUN ayat (4) dan (5) tidak dijelaskan terkait tanggung jawab yang dibebankan padanya berupa tanggung jawab jabatan atau tanggung jawab pribadi, namun jika ditelaah lagi bahwa latar belakang dan semangat perubahan UUPTUN tampak bahwa pasal tersebut merujuk pada tanggung jawab pribadi ${ }^{24}$ sehingga saat ini UU PTUN mengandung muatan tanggung jawab jabatan dan tanggung jawaban pribadi. Namun penerapan tanggung jawab jabatan

\footnotetext{
${ }^{22}$ Tatiek Sri Djatmiati, Tanggung Jawab Pribadi dan Tanggung Jawab Jabatan Loc.Cit.

23 Julista Mustamu, Op.Cit. [7].

24 Julista Mustamu, Loc.Cit.
} 
dan tanggung jawab pribadi bergantung pada hal apa dan bagaimana tindakan pemerintah tersebut dilakukan.

Terkait kewenangan tanggung jawab KASN, jika KASN menjalankan kewenangan tidak berdasarkan peraturan perundang-undangan sehingga tidak sah nya suatu tindakan oleh KASN maka pemangku jabatan bertanggung jawab terhadap tindakannya atas nama jabatan yaitu sebagai KASN. Namun, jika tindakan memangku jabatan tidak sesuai peraturan perundang-undangan karena dipengaruhi oleh pihak lain atau dalam melaksanakan kewenangannya dengan itikad buruk berupa perilaku atau perbuatan melawan hukum, melampaui wewenang, menggunakan wewenang untuk tujuan lain dari yang menjadi tujuan wewenang tersebut, termasuk kelalaian atau pengabaian kewajiban hukum dalam penyelenggaraan pelayanan publik yang dilakukan oleh penyelenggara Negara dan pemerintahan yang menimbulkan kerugian materiil dan/atau immaterial bagi masyarakat dan orang perseorangan yang menyebabkan maladministrasi sehingga yang dibebani tanggung jawab yaitu pribadi pemangku jabatan karena hal tersebut merugikan masyarakat dan berkaitan dengan pribadi memberikan pelayanan pada masyarakat maka berlaku tanggung jawab pribadi padanya.

\section{Pengawasan Komisi Aparatur Sipil Negara dalam Sistem Merit}

Dalam melaksanakan penyelenggaraan pemerintahan, admininistrasi negara mempunyai beberapa keleluasaan tindakan demi terselenggaranya kesejahteraan masyarakat, namun keleluasan yang diberikan harus dapat dipertanggung jawabkan dan berdasarkan asas legalitas. Menurut Lord Acton bahwa kekuasaan sekecil apapun berpotensi disalahgunakan, karena adanya keleluasaan bertindak dalam administrasi negara yang memasuki seluruh sektor kehidupan masyarakat hal ini kemudian hari dapat merugikan masyarakat sendiri. Kemudian diadakan pengawasan terhadap jalannya pemerintahan, yang merupakan bentuk jaminan agar jangan sampai keadaan negara menjadi diktator tanpa batas yang mana hal ini bertentengan dengan ciri negara hukum.

Cara pengawasan dalam penyelenggaraan pemerintah ditinjau dari segi kedudukan badan/organ yang melaksanakan pengawasan yaitu pengawasan intern 
dan pengawasan ektern. ${ }^{25}$ Bahwa pengawasan intern merupakan pengawasan yang dilakukan oleh satu badan secara struktural yang termasuk lingkungan pemerintah. Salah satu bentuk pengawasan internal yaitu pengawasan oleh pejabat yang lebih tinggi jabatannya pada jabatan yang lebih rendah. Sedangkan, pengawasan ekstern yaitu pengawasan yang dilakukan oleh satu badan secara struktural yang berada lingkungan pemerintah (dalam arti eksekutif). Sebagai contoh yaitu Badan Pengawas Keuangan (BPK) merupakanpengawas yang berada di luar pemerintahan (dalam hal ini eksekutif) yang melakukan pengawasan terhadap keuangan terkait bertanggung jawab kepada DPR karena DPR juga merupakan lembaga pengawas ekstern yang mencakup perbuatan pemerintah yang disebut freies ermessen karena DPR dapat melakukan dengar pendapat untuk menanyakan kebijakan yang diambil pemerintah.

Pengawasan oleh Komisi Aparatur Sipil Negara meliputi mengawasi pelaksanaan norma dasar, kode etik, dan kode perilaku ASN, serta penerapan Sistem Merit dalam kebijakan dan Manajemen ASN pada Instansi Pemerintah. Untuk melihat bentuk pengawasan yang dilakukan oleh KASN perlu melihat bentuk lembaga KASN berdsarkan Pasal 27 UU Nomor 5 Tahun 2014, bahwa KASN merupakan lembaga nonstruktural yang mandiri dan bebas dari intervensi politik untuk menciptakan Pegawai ASN yang profesional dan berkinerja, memberikan pelayanan secara adil dan netral, serta menjadi perekat dan pemersatu bangsa.

\section{Kesimpulan}

Komisi Aparatur Sipil Negara sebagai lembaga nonstruktural yang mandiri dan bebas dari intervensi politik berdasarkan Pasal 25 Undang-Undang Nomor 5 Tahun 2014 Tentang Aparatur Sipil Negara memperoleh kewenangan secara delegasi dari Presiden dengan akibat hukum tanggung jawab beralih pada Komisi Aparatur Sipil Negara dalam hal melakukan monitoring dan evaluasi pelaksanaan kebijakan dan manajemen ASN demi menjamin perwujudan Sistem Merit berdasarkan fungsinya.

${ }^{25}$ Diana Halim Koentjoro, Hukum Administrasi Negara (Ghalia Indonesia 2004).[70-75]. 
Dalam Sistem Merit, tanggung jawab KASN pada jabatan melekat saat menjalankan wewenangnya sebagai pejabat pemerintahan melanggar keabsahan tindakan pemerintah berdasarkan peraturan perundang-undangan dan Asas-asas Umum Pemerintahan yang Baik (AUPB) dengan sanksi berupa sanksi administrasi dan sanksi perdata, kemudian pada tanggung jawab sebagai pribadi terjadi saat terdapat maladministrasi dengan indikator tindakan tersebut dalam pelaksanaan tugas terdapat perilaku sewenang-wenang serta penyalahgunaan wewenang yang melanggar peraturan perundangan-undangan dan Asas-asas Umum Pemerintahan yang Baik (AUPB) sehingga tindakan Komisi Aparatur Sipil Negara dalam melaksanakan wewenangnya perlu dilihat secara kasuistik dikategorikan sebagai tanggung jawab pribadi atau tanggung jawab jabatan termasuk dalam pembuatan laporan penilaian pada Kementerian/Lembaga maupun pada instansi pemerintah daerah yakni Provinsi dan Kabupaten/Kota secara berkala yang merupakan bentuk dari pengawasan ekstern dari Komisi Aparatur Sipil Negara dengan tujuan untuk menghindari kesewenangan oleh pemegang kekuasaan.

\section{Daftar Bacaan}

\section{Buku}

Diana Halim Koentjoro, Hukum Administrasi Negara.(Ghalia Indonesia 2004).

Effendi Sofyan, Manajemen Pelayanan Umum (Usaha Nasional 1997).

Jiwo Wungu, Merit System (Raja Grafindo 2003).

Juniarso Ridwan dan Achmad Sodik Sudrajat, Hukum Administrasi dan Pelayanan Publik (Nuansa Cendekia 2019).

Kamal Hidjaz, Efektivitas Penyelenggaraan Kewenangan Dalam Sistem Pemerintahan Daerah di Indonesia (Pustaka Refleksi 2010).

Ridwan HR, Hukum Administrasi negara (Raja Grafindo Persada 2013).

Tatiek Sri Djatmiati et al., Buku Ajar Hukum Perizinan (Fakultas Hukum Universitas Airlangga 2012).

Tatiek Sri Djatmiati, Tanggung Jawab Pribadi dan Tanggung Jawab Jabatan, 
(Alumni Universitas Trisakti 2010).

Tatiek Sri Djatmiati, Hukum Administrasi dan Tindak Pidana Korupsi, (Gadjah Mada University Press 2011).

\section{Jurnal}

Deny Pala'langan, 'Tanggung Gugat Perusahaan Penerbangan terhadap Kehilangan Bagasi Penumpang' (2017) Lex st Societas.

Julista Mustamu, 'Diskresi dan Tanggungjawab Administrasi Pemerintahan', (2011) Jurnal Sasi.

Lukman Hakim, 'Kewenangan Organ Negara Dalam Penyelenggaraan Pemerintahan' (2011) Jurnal Konstitusi.

M. Ikbar Andi Endang, 'Diskresi dan Tanggung Jawab Pejabat Pemerintahan Menurut Undang-Undang Administrasi Pemerintahan', (2018) Jurnal Hukum Peratun.

Wawan dan Rohidin Sudarno, 'Pelaksanaan Sistem Merit Dalam UU ASN, Wewenang KASN dan Analisis Peraturan Perundang-Undangan yang Berpengaruh Terhadap Kewenangan KASN' (2018) Jurnal Mozaik.

\section{Laman}

Komisi Aparatur Sipil Negara, 'Laporan Komisi Aparatur Sipil Negara 2018', (KASN, 2019), <www.KASN.go.id> accessed 14 Agustus 2019.

Merry Tjoanda, 'Analisis Tentang Tanggung Gugat dalam Kontrak Pengadaan Barang dan Jasa', (2019) < https://fhukum.unpatti.ac.id/korupsi/253-analisistentang-tanggung-gugat-dalam-kontrak-pengadaan-barang-dan-jasapemerintah> accessed 15 November 2019.

\section{Perundang-undangan}

Undang-Undang Dasar Negara Republik Indonesia Tahun 1945.

Undang-undang Nomor 8 Tahun 1974 tentang Pokok-Pokok Kepegawaian.

Nomor 3041) Undang-undang Nomor 43 Tahun 1999 tentang Peruabahan atas Undang-undang Nomor 8 Tahun 1974 tentang Pokok-Pokok Kepegawaian.

Undang-Undang Nomor 5 Tahun 2014 tentang Aparatur Sipil Negara. 
Undang-Undang Nomor 30 Tahun 2014 tentang Administrasi Pemerintahan.

Peraturan Pemeritah Nomor 11 Tahun 2017 tentang Manajemen Pegawai Negeri Sipil.

Peraturan Menteri Pendayagunaan Aparatur Negara dan Reformasi Birokrasi Nomor 40 Tahun 2018 tentang Pedoman Sistem Merit dalam Manajemen Aparatur Sipil Negara (ASN). 
1632 Diasa Inas: Kewenangan Komisi Aparatur

--halaman ini sengaja dibiarkan kosong-- 